JAN M. MALECKI

\title{
KULT ŚW. MAGDALENY DE PAZZI W BAROKOWYM KRAKOWIE
}

W drugiej połowie XVII wieku Kraków wszedł w okres upadku. Po wielkiej zarazie lat 1651-1652 i zniszczeniach spowodowanych tragiczna wojną ze Szwecją z trudem dźwigał się z ruin. Liczba ludności wydatnie spadła a życie gospodarcze znacznie osłabło, co było widoczne zwlaszcza w poważnym skurczeniu się obrotów handlowych. Pewne ożywienie następowało tylko w okresie wielkich uroczystości państwowych, tzn. koronacji królewskich i związanych z nimi obrad sejmów koronacyjnych ${ }^{1}$. Szybciej następowała tylko odbudowa obiektów kościelnych. Zdumieniem napawa rychła restauracja zniszczonych kościołów, a nawet wznoszenie nowych budowli sakralnych, nierzadko okazałych i odznaczających się dużymi walorami artystycznymi ${ }^{2}$. Przy równoczesnym znaczeniu książąt-biskupów krakowskich, przybywaniu nowych klasztorów oraz wielkim skupisku obiektów kultu: grobów patronów Królestwa i innych relikwii świętych a także czczonych obrazów - Kraków jawił się jako wielki ośrodek życia religijnego ${ }^{3}$. Ostatnio zaprezentowano nawet interesujący pogląd, iż Polska miała wówczas faktycznie trzy stolice: polityczną w Warszawie, gospodarczą w Gdańsku i w Krakowie - religijnosakralną ${ }^{4}$.

${ }^{1}$ Jan M. Malecki, La dégradation de la capitale (Cracovie aux XVI $I^{e}$ XVII et XVIII siècles). „Studia Historiae Oeconomicae”. Vol. 19: 1986, s. 85-99.

${ }^{2}$ Janina Bieniarzówna, Jan M. Małecki Dzieje Krakowa. T. 2. Kraków w XVI-XVIII wieku. Kraków 1994, s. 405-421.

${ }^{3}$ Piotr Hiacynt Pruszcz, Klejnoty stolecznego miasta Krakowa albo kościoly $i$ co w nich jest widzenia godnego i znacznego krótko opisane... Kraków 1745.

${ }^{4}$ Maria Bogucka, Kraków-Warszawa-Gdańsk: trójkąt stoleczności jako wyraz policentryzmu polskiej urbanizacji. W: Kraków-Malopolska w Europie srodka. Kraków 1996, s. $73-77$. 
Utrwalona w Krakowie tradycja okazałych obchodów państwowych i kościelnych, wywodząca się z poprzedniego okresu świetności miasta, teraz się utrzymywała przybierając właściwe epoce barokowe formy. $\mathrm{Na}$ te, pompatyczne często uroczystości nie szczędzono kosztów. Odbywano je przy okazji wjazdów królów i królowych na koronacje i wesela, przy okazji królewskich pogrzebów oraz odnoszonych zwycięstw (jak po powrocie Jana III spod Wiednia). Z wielka świetnościa odbywano też uroczystości religijne. Było ich w barokowym Krakowie wiele 5 . Jedna z takich uroczystości, mianowicie obchód ku czci św. Magdaleny de Pazzi w 1669 r., choć równie okazała, doczekała się w literaturze naukowej tylko krótkiej wzmianki'. Zasługuje zaś z różnych względów na bliższe przypomnienie.

Katarzyna de Pazzi, w zakonie Maria Magdalena (1566-1607), pochodzaca ze znakomitej rodziny florenckiej i karmelitanka dawnej obserwancji w klasztorze Matki Boskiej Anielskiej we Florencji, zasłynęła jako wielka mistyczka, czcicielka Męki Pańskiej, stygmatyczka. Kult jej rozpowszechnił się przede wszystkim we Wloszech, dotarl również szybko do Polski, szerzony glównie przez karmelitów trzewiczkowych. Już w $1628 \mathrm{r}$., tj. dwa lata po beatyfikacji Marii Magdaleny, w kościele karmelitów na przedmieściu Halickim we Lwowie obchodzono uroczyście jej święto. W tymże roku ukazaly się dwa druczki na jej cześć pióra o. Wojciecha Czepiela, lwowskiego karmelity trzewiczkowego ${ }^{7}$ : jeden stanowiący wierszowany opis wspomnianej uroczystości ${ }^{8}$, drugi obszerniejszy o charakterze hagiograficznym ${ }^{9}$.

Kult mistyczki florenckiej wzmógł sie jeszcze w Rzeczypospolitej po kanonizacji dokonanej przez Klemensa IX 28 IV 1669 r. - tym bardziej, że do pokrewieństwa $\mathrm{z}$ nową święta przyznawał się możny litewski ród Paców ${ }^{10}$. Biskup wileński Mikołaj Stefan Pac (zm. w 1684 r.) miał wówczas otrzymać od „księcia florenckiego" (zapewne chodzi o wielkiego księcia toskańskiego Ferdynanda II lub jego syna Kuźmę III) relikwie św. Marii Magdaleny: ząb

${ }^{5}$ Michał Rożek, Uroczystości w barokowym Krakowie. Kiaków 1976.

${ }^{6}$ Tamże, s. 238

${ }^{7}$ Stownik polskich teologów katolickich. T. 1. Warszawa 1981, s. 350.

${ }^{8}$ Kredencja nabożna B. Maryi Magdalenie de Pazis zakonu karmelitańskiego. Lwów (1628). Cyt. za Bibliografia polską Estreichera, t. 14, s. 563, t. 24 s. 173.

${ }^{9}$ Vita, miracula et transitus B. Mariae Magdalenae de Pazzi, libri 2. Cracoviae 1628. Cyt. za Bibliografią polską Estreichera, t. 14 s. 563.

${ }^{10}$ Zgodnie $\mathrm{z}$ obyczajem sarmackim nakazującym poszukiwania antenatów w starożytnym Rzymie Pacowie herbu Gozdawa wywodzili swój ród od arcykapłana Cosimusa Pacciusa $z$ I wieku przed Chr., podobieństwo zaś nazwiska i herbu kazalo im wierzyć w pokrewieństwo z florencką rodziną de Pazzi. - Marek Cetwiński, Marek Derwich, Herby, legendy, dawne mity. Wrocław 1989, s. 18. 
oprawny w zloto i włosy w oprawie kryształowej, wraz z listem uznajacym pokrewieństwo między świętą a litewskimi Pacami ${ }^{11}$.

Największe uroczystości po kanonizacji odbyły się jednak w Krakowie, u karmelitów na Piasku. W tamtejszym konwencie interesowano się żywo procesem kanonizacyjnym. Świadczą o tym wpisy dokumentów tyczących tej sprawy do księgi protokołów kapituły prowincjalnej, m.in. pisma generała zakonu z 22 IX 1668 r. o przygotowaniach do kanonizacji (instrumentum pro canonisatione) ${ }^{12}$, odpisu bulli kanonizacyjnej Klemensa $I^{13}{ }^{13}$, wreszcie pisma prowincjała Marcina Charzewicza z 12 VIII 1669 r. zawiadamiajacego o kanonizacji, a także zapowiadającego obchody krakowskie ${ }^{14}$.

Tak się zaś złożyło, że obchody te mogły przybrać szczególnie uroczystą postać. W tymże bowiem 1669 roku, po abdykacji Jana Kazimierza, odbyła się kolejna elekcja królewska: 19 VI nowym monarchą obrano Michała Korybuta Wiśniowieckiego. Sejm koronacyjny zwolano na $1 \mathrm{X}$ do Krakowa. Sama koronacja odbyła się w katedrze wawelskiej w dniu imienin elekta: 29 IX. Koronował prymas Mikołaj Prażmowski w obecności dygnitarzy koronnych i litewskich oraz reprezentantów dworów zagranicznych. Do Krakowa zjechali też posłowie sejmowi. $1 \mathrm{X}$ rozpoczęly się burzliwe obrady na zamku wawelskim i trwaly do $7 \mathrm{XI}$, kiedy to zostały zerwane (pierwsze to w dziejach Polski zerwanie sejmu koronacyjnego). Senat obradowal jeszcze 16 XI. Tymczasem król pozostał w Krakowie do 4 XII i poza zajęciami zwiazanymi z obowiązkami monarszymi odwiedzal miejscowe kościoły ${ }^{15}$.

W takich okolicznościach 2 i 3 XI 1669 r. urządzono uroczysty obchód dla uczczenia kanonizacji Marii Magdaleny de Pazzi. Według współczesnej relacji miał on przebieg bardzo okazały. W sobotę 2 XI po południu przeniesiono procesjonalnie obraz św. Magdaleny z kościoła Dominikanów do karmelitów na Piasku. Pochód, idący przez bramę Floriańską i Kleparz, uformował się $w$ następujący sposób. Najpierw szly bractwa $z$ choragwiami, potem w podwójnych rzędach zakonnicy z siedmiu zgromadzeń, oddzial piechoty w strojach węgierskich ( $\mathrm{z}$ okazji sejmu wiele było w Krakowie wojska), orkiestra wojskowa i za nia muzykanci zebrani z kapel senatorskich. Niesiono świeżo malowaną chorągiew $\mathrm{z}$ wyobrażeniem świętej jak również relikwie

${ }^{11}$ Kasper Niesiecki, Herbarz polski. Wyd. Jan Nepomucen Bobrowski. T. 7. Lipsk 1841 , s. 219.

${ }^{12}$ Archiwum Prowincji Karmelitów w Krakowie (AKK) rkps 94/450, k. 11-12. - Za umożliwienie mi dostępu do zbiorów archiwalnych dziękuję p. drowi Wacławowi Kolakowi.

13 Tamże, k. 13.

${ }^{14}$ Tamże, k. 14 i n.

15 Adam Przyboś, Michal Korybut Wiśniowiecki 1640-1673. Kraków 1984, s. 57, $78-94$. 
w srebrnej trumience (welum zakonne Marii Magdaleny). Towarzyszyli im ojcowie karmelici z pochodniami. Wreszcie czterej karmelici w dalmatykach nieśli obraz świętej „wybornie i kosztownie przyozdobiony w nieoszacowane klejnoty, perly, łańcuchy, drogie kamienie". Za obrazem postępowali przedstawiciele Akademii, szlachta, biskup sufragan krakowski Mikołaj Oborski w stroju pontyfikalnym, duchowieństwo diecezjalne, senatorowie, rada miejska i tlumy wiernych. Wiclu obserwowało procesję z okien, dachów i chodników. Gdy pochód znalazł się na przedmieściu Piasck, oddano strzały na wiwat z hakownic na ratuszu miejskim i z dział ustawionych między murami klasztornymi. W kościele odprawiano nabożeństwo do późnego wieczora. Następnego dnia: 3 XI uroczystą mszę świętą odprawił biskup kijowski Tomasz Ujejski (pełniący wówczas funkcję sufragana warmińskiego). Obecnych było na niej wielu biskupów i senatorów świeckich a również sam król ${ }^{16}$. Kazanie w barokowym stylu, wygłosił reformata o. Franciszek Wolski. Nawiązał do kanonizacji Magdaleny („Uroczystość kanonizacjej obchodziemy: dobra nasza"), a równocześnie do przypadającej na niedzielę ewangelii o talentach, co mu pozwoliło wyrazić modlitewną prośbę o „kwietacją zupełną Ojczyzny naszej, abyśmy przez Miłosierdzie Boskie z grzechów uwolnieni, doczesnym i wiecznym byli obdarowani kwitem"17.

Kazanie to zostało opublikowane przez krakowską drukarnię Stanisława Piotrkowczyka i dedykowane przez autora matce króla Gryzeldzie Wiśniowieckiej, także obecnej wówczas w Krakowie, z życzeniem szczęśliwego panowania nowego wladcy ${ }^{18}$. Poważnym osiagnięciem wydawniczym, związanym z obchodami kanonizacyjnymi, stało się opublikowanie w 1671 r. w drukarni spadkobierców Krzysztofa Schedla bardzo obszernego dzieła (460 stron) na temat nowej świętej pt. „Lilia florencka"19. Jest to tłumaczenie z włoskiego, dokonane u karmelitów krakowskich, zapewne przez wspomnianego o. Marcina Charzewicza ${ }^{20}$. Dzieło to stanowi szczegółowy opis życia i dokonań

${ }^{16}$ Lilia florencka albo cudowny żywot serafickiej panny S.M. Magdaleny de Pazzis $z$ miasta Florencjej, zakonu karmelitańskiego dawnej obsenwancjej zakonnej, teraz nowo $z$ wloskiego jezzyka na polski przelożony... Kraków 1671, s. 416-420.

${ }^{17}$ Franciszek Wolscius, Mons pietatis abo góra Karmelu w górę pobożności przemieniona, w której nieoszacowane summy depozytowane cnót i zaslug i przykladów serafińskiej panny Maryej Magdaleny de Pazzis karmelitanki... Kraków 1670. - Fr. Wolski (zm. w 1685 r.) był bardzo popularnym kaznodzieją krakowskim, zapraszanym do wielu kościołów. Później (w 1677 r.) za sprawą króla Jana III Sobieskiego został mianowany kaznodzieją apostolskim na Polskę i Litwę dla propagowania krucjaty przeciw Turkom (Jan Pasiecznik, Działalność klasztoru franciszkanów-reformatów w Krakowie 1625-1978. Kraków 1980, s. $66-67,156)$.

${ }^{18}$ Tamże.

19 Zob. przyp. 16.

${ }^{20}$ Por. Estreicher, Bibliografia polska, t. 14 s. 148. 
św. Magdaleny de Pazzi. Oryginał ukazał się we Włoszech w 1629 r. Wydanie polskie zostało uzupełnione: dodano informacje o cudach dokonanych po beatyfikacji, o kanonizacji i uroczystościach krakowskich, a także dedykację Gryzeldzie Wiśniowieckiej i rymowany wstęp wyrażający radość ziemi polskiej z tego, iż karmelici „przesadzili kwiat zapachu cnego w lacki wirytarz z ogrodu włoskiego"21.

W 1669 r. kościół Karmelitów nie był jeszcze zupełnie odrestaurowany po zniszczeniach wojennych. Jego powtórna konsekracja po odnowieniu nastapiła dopiero dziesięć lat później. Dokonał jej biskup Mikołaj Oborski 23 IV $1679 \mathrm{r}$. i wtedy poświęcił też nowo wzniesiony w nawie południowej ołtarz św. Magdaleny de Pazzi ${ }^{22}$. Stał się on trwałą pamiątką uroczystości z 1669 r.

W wieku XVIII utrzymywał się u krakowskich karmelitów trzewiczkowych kult świętej ${ }^{23}$. Odprawiano uroczyste nabożeństwa i wygłaszano stosowne kazania, szczególnie w dniu jej święta, obchodzonego wówczas 29 maja. W czasie takich nabożeństw w kościele Karmelitów na Piasku popisywali się łacińskimi mowami na cześć św. Magdaleny studenci Wydziału Filozoficznego Akademii Krakowskiej, prezentując w ten sposób swoje umiejętności $\mathrm{z}$ retoryki. Mowy te bywały drukowane i pod ta postacia kilka $\mathrm{z}$ nich się zachowało. Niedługo po nowych klęskach, jakie nawiedziły Kraków (zniszczenia w czasie wojny północnej, wielka zaraza z 1707-1708 r.), 29 V 1712 odbyło się uroczyste nabożeństwo na Piasku. Kunsztownie zbudowaną łacińską mowę wygłosił wówczas Każmierz Benedykt Wilkoński. Wzywał św. Magdalenę, porównaną do muszli pełnej pereł, by wstawiła się za zubożałym państwem i popadajacym w ruinę Krakowem (,concha es, plena margaritis, quibus et Regni egestatem tollere et urbis huius - ut saepe saepius Florentiae soles ruinae subvenire potes optime") $)^{24}$.

W niedzielę 27 V 1725 r. na nabożeństwie w kościele Karmelitów na Piasku łacińską mowę na cześć św. Magdaleny wygłosił Jan Antoni Bylina z Leszczyn. Zakończył modlitwą do świętej, by za jej wstawiennictwem omi-

${ }^{21}$ Lilia florencka..., s. nlb. 17.

${ }^{22}$ Jan Kracik, Konsekracje kościolów i oltarzy w diecezji krakowskiej w XVII-XVIII wieku. „Nasza Przeszlość”, T. 61: 1984, s. 116, 134; por. też AKK Perg. 41 (pergaminowy dokument biskupa Oborskiego o konsekracji).

${ }^{23}$ Podobnie było $w$ ośrodkach karmelitańskich poza Krakowem. Jako przykład tego kultu może służyć konsekracja, jeszcze w 1679 r, oltarza świętej w kościele karmelitów w Woli Gułowskiej koło Lukowa (J. Kracik, Konsekracja kościolów..., s. 145), czy wydanie w Berdyczowie w 1779 r. jej biografii (Estreicher: Bibliografia polska, t. 24 s. 173).

${ }^{24}$ Casimirus Benedictus Odrowąż a Wilkowice Wilkonski, Concha virtutum in Mari Mariana praestantissima, D. Maria Magdalena de Pazzis, annuo suae festivitatis recurrente die, in basilica celeberrimi conventus Cracoviensis maioris perantiquae regularis obseruantiae PP. Carmelitarum... demonstrata. Cracoviae 1712 
nęły Polskę wszelkie nieszczęścia („fac, Virgo Divissima, ut Tua intercessione nulla Poloniae insultuum et infortuniorum noceant monstra") oraz by otaczała opieką uniwersytet (,Alma studiorum Mater, Regni generalis schola universitas Cracoviensis sit ab omnibus adversis sub Tua protectione secura") ${ }^{25}$.

Podobnie było w następnych latach. Podczas nabożeństwa $25 \mathrm{~V} 1766 \mathrm{r}$. mowę łacińską mial Józef Kazimierz Straszewski ${ }^{26}$, a w niedzielę $30 \mathrm{~V} 1773$ r. - Waclaw Michał Skorupka ${ }^{27}$.

Obok tych nabożeństw z uczonymi mowami po łacinie wprowadzano też inne formy kultu świętej, przeznaczone dla szerszego kręgu jej czcicieli, a szczególnie dla członków arcybractwa szkaplerza świętego. W XVIII-wiecznym druku zawierającym w jednym tomie modlitwy tego bractwa wraz $\mathrm{z}$ wykazem przysługujących mu przywilejów i odpustów znajdują się również „godzinki o serafickiej pannie S. Maryej Magdalenie de Pazzis zakonu karmelitańskiego" oraz litania do św. Marii Magdaleny ${ }^{28}$

W XVIII w. karmelici zdolali bardzo ubogacić wnętrze swego kościoła. Na początku tego stulecia pokryto freskami sklepienia i ściany naw bocznych (przemienionych teraz wlaściwie na kaplice). Przy oltarzu św. Magdaleny de Pazzi freski te przedstawiaja sceny z jej życia ${ }^{29}$. W XVIII w. otrzymał zapewne oltarz swój obecny kształt: bardzo bogaty, z ozdobami w stylu rejencji i rokoka. Obraz świętej namalował na przełomie XVIII i XIX w. Michał Stachowicz $^{30}$. Artysta przedstawil św. Magdalenę w ckstazie, gdy ukazal się jcj św. Augustyn wyjaśniając tajemnicę Wcielenia zawartą w rozważanych przez młodą wówczas nowicjuszkę słowach z Ewangelii św. Jana: „Verbum caro factum est" ${ }^{\prime 31}$.

${ }^{25}$ Joannes Antonius Bylina de Leszczyny, Prodigium montis Carmeli D. Maria Magdalena de Pazzis miraculis et vitae sanctitate inclarescens.. Cracoviae (1725).

${ }^{26}$ Josephus Casimirus Radwan de Straszewy Straszewski, Ipsum velle Dei in vita sua amplexa fuisse seraphica virgo S. Magdalena de Pazzis..., Cracoviae 1766.

${ }^{27}$ Venceslaus Michael Skorupka, Oratio in laudem D. Magdalenae de Pazzis recurrente sacro suo nomini die... (Cracoviae 1773).

${ }^{28}$ W Bibliotece Jagiellońskiej zachowało się trzecie wydanie tej publikacji (Kraków: Drukamia Akadomicka 1732) pt. Koronka szkaplerza S. Panny Przenajświętszej Maryi... Autor kryje się pod kryptonimem X.K.S.K.P.B.S.S.

${ }^{29}$ Władysław Włodarczyk, Kościól Karmelitów na Piasku. „Rocznik Krakowski”. T. 36: 1963, s. 136.

${ }^{30}$ Tak przyjmują historycy sztuki (por. W. Włodarczyk, Kościól Karmelitów..., s. 138; Michał Rożek, Kościól oo. Karmelitów na Piasku w Krakowie. Przewodnik dla zwiedzajacych. Kraków 1990, s. 14) na podstawie wzmianki u Edwarda Rastawieckiego (Słownik malarzów polskich. T. 2. Warszawa 1851, s. 206), iż Michał Stachowicz wykonał dla karmelitów na Piasku 4 obrazy, m. in. „św. Magdaleny”. - Za potwierdzenie informacji o autorstwie Stachowicza dziękuję p. prof. Janowi Samkowi.

${ }^{31}$ Informację na temat tego zdarzenia, które miało mieć miejsce 24 III 1585 r., zaczerpnął artysta niewątpliwie z Lilii florenckiej (por. przyp. 16) s. 40-41. - Jest to raczej 
Kult św. Marii Magdaleny de Pazzi - mimo swego bardzo uroczystego zapoczątkowania - nie rozwinął się jednak w sposób bardzo znaczący. Został rychło zdominowany przez wzrastająca szybko, zwłaszcza po wojnie szwcdzkiej 1655-1657 r., cześć wizerunku Matki Boskiej Piaskowej ${ }^{32}$. Świadczy o tym obszerne opracowanic Mikołaja Grodzińskiego z 1673 r. poświęcone wylącznie cudownemu obrazowi ${ }^{33}$. W znanym przewodniku po kościołach Krakowa Piotra H. Pruszcza z 1745 r., przy opisie kościoła Karmelitów na Piasku nie ma w ogóle mowy o oltarzu ani o kulcie św. Magdaleny. Wymieniono tylko jakąś jej relikwię wśród przechowywanych w kościele bardzo licznych relikwii innych świętych ${ }^{34}$.

W XIX wieku kult, jak się zdaje, zanikł zupełnie. Nie wspominają o nim ogólne przewodniki po Krakowie. Natomiast najobszerniejsza jak dotąd monografia historyczna kościola Karmelitów pióra Jana Rogalskiego opisuje krótko oltarz świętej na równi z innymi stanowiącymi wyposażenic wnętrza ${ }^{35}$. Równie krótko wymienia ołtarz św. Magdaleny de Pazzi inwentarz kościola z $1869 \mathrm{r}^{36}$. Nie urządzano też już w XIX w. uroczystych nabożeństw w dniu 29 maja $^{37}$. Być może do tego zaniku kultu przyczyniły się perypetie klasztoru karmelitów trzewiczkowych, kiedy to w $1801 \mathrm{r}$. przeniesiono tu parafię św. Szczepana a zarząd kościoła przejęli księża diecezjalni. Niedlugo potem (w 1813 r.) zamknięto nowicjat i groziła wręcz kasata klasztoru. Aż do roku 1929, kiedy to przeniesiono parafię do kościoła św. Marka, trwały ustawiczne zatargi zakonników z księżmi diecezjalnymi, a wnętrze kościoła (oprócz kaplicy cudownego obrazu, którą opiekowali się karmelici) popadało w stan zanicdbania. Gdy jednak po 1929 r. nowy prowincjał zakonu Sanchez Paredes

rzadkie przedstawienie ikonograficzne świętej (por. Lexikon der christlichen Ikonographie. Husg. Wolfgang Braunfels. Bd. 7. Freiburg 1990, s. 542-543).

${ }^{32} \mathrm{Na}$ ten temat szerzej Janina Bieniarzówna, Antoni T. Piotrowski, Sanktuarium Maryjne w kościele oo. Karmelitów na Piasku w Krakowie. Dzieje kultu $i$ kaplicy. Kraków 1983.

${ }^{33}$ Ogród fiolkowy karmelitański na Piasku przy Krakowie od Najjaśniejszej nieba i ziemie Królowej, Przenajświętszej Maryej Panny zdawna obrany i ulubiony jedynie... Kraków 1673.

${ }^{34}$ P.H. Pruszcz, Klejnoty..., s. 168 . - W poprzednich wydaniach książki (z 1647 i 1650 r.) nie mogło oczywiście być mowy o św. Magdalenie de Pazzi.

${ }^{35}$ Jan Rogalski, Kościól na Piasku czyli opis historyczny zatożenia i rozwoju kościoła oo. karmelitów na Piasku w Krakowie..., Kraków 1863, s. 131-132. - Późniejsze opracowanie Romualda Kaczkowskiego (Historia o kościele oo. Karmelitów i kaplicy na Piasku. Kraków 1873) koncentruje się na historii cudownego obrazu Matki Boskiej Piaskowej.

${ }^{36}$ AKK, rkps 648, s. 31 .

${ }^{37}$ Kalendarz Krakowski Józefa Czecha aź do tomu 83 na rok 1914 podawał na każdy miesiąc wykaz odpustów i uroczystych nabożenstw wotywnych w kościołach krakowskich. Nie wymienia się w nim takich nabożeństw ku czci św. Marii Magdaleny de Pazzi. 
przeprowadził restaurację kościoła - gruntowną, ale nie liczącą się z wymogami konserwatorskimi i usunąl wiele ołtarzy, kaplica św. Magdaleny de Pazzi ocalała wraz z XVIII-wiecznymi freskami i ottarzem, który zachował swą barokową okazałość co $^{38}$.

Epizod związany z kultem św. Marii Magdaleny de Pazzi nie był w dziejach Krakowa szczególnie znaczący. Przebieg uroczystości kościelnych z $1669 \mathrm{r}$. jest jednak dobrym przykładem okazałości obchodów barokowych w zrujnowanym wojnami Krakowie oraz ożywiania się podupadłego miasta, pozbawionego od dawna charakteru rezydencjonalnego, podczas pobytu króla i obrad scjmu. Zapewne też może być przedmiotem refleksji nad wpływem czynników zewnętrznych na rozwój i zanik kultu niektórych świętych.

${ }^{38}$ W. Włodarczyk, Kościól Karmelitów..., s. 133, ryc. 7; M. Rożek, Uroczystości... ryc. 5 . 